\title{
CEDAW IN THE EYES OF THE UNITED STATES
}

\author{
Al Shraideh, Saleh \\ College of Law, The American University in the Emirates \\ The International Academic City, Dubai, United Arab Emirates \\ Saleh.alshraideh@aue.ae
}

(Received October 2017; Accepted November 2017)

\begin{abstract}
:
Despite the large number of reservations registered by Member countries, making it one of the, if not the, most heavily reserved human rights treaties; the Convention on the Elimination of All Forms of Discrimination Against Women (CEDAW) has managed to achieve a very high rate of states' membership [1]. Currently, 187 countries out of the 193 United Nations Members are parties to CEDAW [2]. What is strange to digest, however, is the fact that the United States is one of the seven countries that are yet to ratify the Convention [3]. This article provides an insight into the position of the United States from the ratification of CEDAW. It examines the merits of arguments made for and against the ratification and their rationale to provide a better understanding that explains what is considered by many as a buzzling stand of the United States from the Convention.
\end{abstract}

\section{Keywords: United States, CEDAW, Ratification, Women rights}

\section{Introduction}

The Convention on the Elimination of All Forms of Discrimination Against Women (CEDAW) was adopted by the United Nations General Assembly in 1979 after the First World Conference on Women in 1975 witnessed the call for a treaty for the Rights of Women [4], as there was a lack, at the time, for an international reference point that addresses women's basic human rights in a comprehensive way that deals with all aspects of women's existence in a society.

CEDAW, which is widely considered as the "Bill of Rights" for women requires, as an international legal instrument, respect for women's rights, and implementation of all aspects of gender equality, expecting from its ratifying countries to actively promote such equality and to eliminate all forms of discrimination against women. The Convention covers a wide range of issues that focus on three main aspects that affect women's existence in society. It focuses on their civil rights and legal status in all areas of activity; human reproduction with an emphasis on maternity, employment, family law, and health education; and the impact of cultural factors including traditions, stereotypes, customs, and norms that perpetuate the discrimination of women in all areas of society [5].

Many consider the Convention innovative in addressing women rights because they believe that CEDAW: 
has been credited with evolving the concept of substantive equality, a foil to the conventional model of formal equality. The underlying basis of formal equality is that like should be treated alike - that those who are similarly situated be treated similarly. Formal equality denotes that among equals, laws should be equal and equally administered. Consequently, the argument would continue, that when groups are not similarly situated, they do not qualify for equality even if the differences among them are the product of historic or systemic discrimination. That women can be different from men but still equal to them is one way of looking at the new idea of equality the Convention tries to establish [6].

The enforcement of the Convention is left to Member countries to decide without a self-executing power of the Convention for its implementation [7]. However, to oversee and review the implementation process of Members, the Convention established, through Article XVII, a monitoring body, Committee on the Elimination of Discrimination Against Women (CEDAW Committee), which is equipped with the task of reviewing periodic reports presented by Members to demonstrate their progress in the process of implementation for the purpose of assessing their performance [8]. However, the Committee does not have an authority to carry out any action against self-reported non-complying Members other than submitting an annual report to the United Nation's General Assembly, showing the position of each Member state with regards to the performance of its commitments under the Convention. The Committee, in exercising its role in reviewing Members' reports, enjoys freedom in conducting its analysis on various methods of implementation of Member countries, and adopting what they deem as appropriate interpretations to the Convention's text to serve its purpose, taking into consideration Member countries' commitments [9].

Human rights in the United States are a complex issue with varying opinions. Despite the fact that human rights in the United States are legally protected by the constitution and the amendments, federal legislation, state constitutions, and state legislations, which reflects the general attitude of the country embodied in the American Declaration of Independence at the early stages of the country's existence; the record of the United States implementation of such rights has been subject to international criticism in relation to some issues. The United States is argued to have breached some of the basic human rights through a number of questionable practices and policies, such as invasion of privacy [10], surveillance programs [11], and mistreatment of prisoners [12], Guantanamo Bay detention program [13], and support for foreign dictators who are accused of documented human rights violations [14]. However, the overall extent of the its embracement of and adherence to human rights principles and protection is still considerable and ranking very well globally [15]. 
The United States position towards gender equality has been part of its overall position in relation to equality as one of the basic human rights protected by the its legal system. In this regard, The United States introduced the Nineteenth Amendment to its Constitution, which prohibits the states and the federal government from denying any citizen the right to vote because of that citizen's sex [16]. It has also enacted a comprehensive Civil Rights Act in 1964 that prohibits discrimination on the basis of gender in the workplace [17], in addition to introducing anti-discrimination government enforcement bodies, such as the Equal Employment Opportunity Commission [18].

Despite its recognition to the principle of gender equality, which is reflected in context of its legal, judicial, and political framework, the United States has failed so far to acknowledge the international standards created to support and consolidate such principle by not ratifying a treaty that represent a set of internationally agreed on aspects through which the protection of gender equality is achieved. Many believe that the United States, being one of the most developed countries in the world, fails to acknowledge that the impact of its ratification of CEDAW would set a strong tone of importance to many other countries that look up to it as an example in setting up their domestic policies. They believe that the United States could then be able to lead by example, and provide suggestive solutions to the countries struggling in narrowing the gender gap in their societies in various fields, which would affirm the self-declared role of the United States as one of the global leaders in human rights. Hence, realizing all this, what are the factors that have been obstructing the United States from the ratification of CEDAW despite nearly thirty years of its existence?

\section{Analysis of the debate surrounding the US ratification of CEDAW}

As a starting point, it is relevant to outline the process of international treaties' ratification in the United States to develop an understanding on where CEDAW is currently at and has been in the ratification process. The ratification process begins when the United States President submits the treaty, after signature, to the Senate where it is automatically forwarded to the Committee of Foreign Relations for consideration [19]. Unless the Committee, represented by its Chairman, decides to present it to the full Senate through scheduling a vote on the treaty, it remains in the Committee [20]. If a treaty was chosen to be presented before the Senate for voting, and achieved a two-thirds approving majority, the president can then ratify it on behalf of the United States [21]. After nearly three decades, CEDAW has not yet presented before the Senate for a vote.

Even though the United States is regarded by many around the globe as a leading example in the protection of civil rights and liberties, the American society is still considered as largely conservative with regards to many issues that could be 
closely associated with civil rights. This conservativeness has, in turn, affected the position of the United States from CEDAW Convention, leading to its reluctance or inability to show a commitment towards the Convention through a legally binding ratification [22]. However, is the opposition of the conservative wing of the United States society, which has successfully managed so far to create a reluctant position of the United States towards the Convention, really warranted?

The argument against the Convention is concentrated on the threat it might pose to the sovereignty of the United States, and the impact it might have on the country's ability to decide policies that fall within the scope of application of the Convention, as it would push the country to renounce too much power to the international community as a result of having the Convention provisions subrogating its law [23].

This argument might not exist or gain momentum, as it is the case in the United States, if the subject of the debate was relating to a different treaty, as it is a widely accepted principle now that international obligations resulted mainly from international treaties have supremacy over conflicting domestic legislations or policies of countries parties to such treaties. It is generally recognized that the parties to an international treaty have an obligation, whether explicit or implicit, to facilitate the successful function of the treaty and contribute in achieving its desired outcome, which would more likely involve renouncing part of its sovereignty in the field of the treaty's specialization. This issue has not been, to a large extent, an obstacle in the philosophy of the United States' international commitment and policies, which is evident in the number of international organizations or treaties it is part of. However, the subject of the Convention and the issues that relate directly or indirectly to the functioning of its purpose play a major role for the concerns of the opposition over losing control in favor of implementing international obligations. To be more specific, there is a concern that the elimination of all forms of discrimination against women would be loosely interpreted to affect some of the most sensitive issues in the United States society, such as marriage, motherhood, or family structure, which are considered as traditional moral and social values [24]. In this regard, family structure in the traditional sense of the concept is considered as the cornerstone not only in the United States society, but also in any given society; and the disruption to the natural distribution of rights and obligations in the function and structure of the family is viewed by many to have a potential detrimental effect on the society as a whole. One could argue that Article 5 of the Convention seeks the elimination of all practices that are based on certain stereotyped roles for men and women, including those relating to family responsibilities in a way that does not reflect an understanding to some key aspects associated with the identity of men and women and the natural differences that exist between them as a mankind [25]. In this context, the language of the 
Convention does not reflect common-sense recognition that the natural roles of men and women in a family were not designed to be based upon the idea of superiority of either, but on the idea that they complement one another. It could be said that the Convention does not seek the regulation and structuring of family life. Instead, the Convention seeks to eliminate current prejudices affecting the integrity of the principle of social equality for women that are caused by traditional gender perceptions [26]. It seeks to do so through the promotion and development of public information and education programs that recognize the common responsibility of men and women in the upbringing and development of their children in a way that achieve their best interests rather than a direct interference with parenting roles and responsibility, which is consistent with the existing legal system of the United States [27]. It could be argued, however, that some rulings of the CEDAW Committee show a view that is inconsistent with the declared purpose of the Article. The rulings in question could be argued to have clear indication of the Committee's tendency to restrict women's roles as mothers and caregivers.

In this context, the Committee, for example, suggested in 1998 that in Croatia there is a "need for measures to eliminate stereotypes that restrict women's role to that of mothers and caregivers [28]." In 2001, the Committee noted in case of Kazakhstan "that a shift from focus on women solely as wives and mothers, to individuals and actors equal to men in society is required for the full implementation of the Convention [29]." Also, in 2000, the Committee expressed its concern over "the stereotypical attitudes that tend to portray men as heads of households and breadwinners and women primarily as mothers and homemakers" that it claims to exist in Luxembourg [30].

Related to family structure, the issues of abortion and same-sex marriage have been subject to a nation-wide debate with a considerable part of the United States society expressing its reservations on the two issues. Like family structure, there is a concern that the ratification of CEDAW would result in a unwelcomed foreign interference in two of the most morally and legally sensitive issues in the United States.

In relation to abortion, the convention is viewed by its opponents to promote abortion, as it might consider it as one form of discrimination against women in their access to health services [31]. However, it could be argued in this regard that the Convention does not refer to abortion in any of its rules [32], which should downplay the concern over the consequences of the ratification of the Convention by the United States on a controversially dividing issue like abortion. This argument supports its view with the fact that some countries, such as Ireland and Rwanda, have ratified the Convention despite criminalizing abortion in their domestic laws, which proves, according to the argument, that there is no conflict between the ratification of the Convention and adopting a certain legal position 
towards abortion [33]. In addition, the State Department stated that the Convention is "abortion neutral", and the Senate Foreign Relations Committee added in its understanding to the Convention that Article 12, dealing with women rights to health care services does not include a right to an abortion [34].

It is true that the silence of CEDAW on abortion could be used to dismiss criticisms of its promotion of abortion, but it also could be argued that it is not necessary of abortion to be mentioned explicitly in the Convention in order for it to be promoted. The interpretation of CEDAW Committee in this regard would lead exactly to the same outcome by classifying abortion and other controversial policies as rights [35]. In this regard, for example, women rights to access health care services including those related to family planning, which is stated in Article 12 of the Convention, was interpreted by the Committee to include the right to abortion in the Committee's "General Recommendation 24" in which it stated in its interpretation to the health care services article that "when possible, legislation criminalizing abortion should be amended", and that states "must also put in place a system that ensures effective judicial action [36]. Failure to do so will constitute a violation of Article 12 [37]". Such interpretation was also reflected in the understanding of the United States' ratification with the CEDAW Committee, which stated that "abortion rights are in the spirit of the treaty [38]", explaining that abortion rights are implicit in the Convention throughout its articles, including article 12 on health services [39].

The issue of same-sex marriages had also been a dividing issue in determining the United States' position from CEDAW. One of the concerns over its ratification of the Convention was that the Convention could lead to legalizing same-sex marriages [40]. Despite the argument that the terms of the Convention are clearly targeting exclusively sex-based discrimination against women, without any reference to same-sex marriage as an issue, referring to the fact that many countries that ban same-sex marriage have already ratified the Convention [41]; this issue is irrelevant in context of debating the ratification of the United States of the Convention. This irrelevance is due to that fact that regardless to the position of CEDAW from same-sex marriages, the United States has legalized same-sex marriage nation-wide, when its Supreme Court ruled in the landmark case of Obergefell $v$. Hodges that state-level bans on same-sex-marriage were unconstitutional [42].

However, for the sake of argument, the view that the Convention does not put same-sex marriage within its mandate, but rather sex-based discrimination in marriage and family relations seems to be more rational. The purpose of the Convention is to eliminate all forms of discrimination where men are granted superior rights based on their gender, including in marriage. The ban on same-sex marriage in the United States used to affect, however, both men and women in their

DE GRUYTER OPEN 
view on what forms a marital relationship. This means that there was no discrimination in this issue between the two sexes, which logically excludes it from the Convention's scope of implementation.

Another concern relates to the impact of the United States ratification of CEDAW on single-sex schools, arguing that the Convention's implementation would threaten the existence of such schools, and would also place an additional burden on public schools to provide "gender-neutral" teaching materials, which would put an undesired and unneeded restrictions [43]. This argument is countered by assurances that single-sex schools are not restricted or prohibited by the language of the Convention, which only refers to the need for implementation of educational equality for both sexes, taking it into account in education facilities, materials, or any other education-related aspect regardless to whether in single-sex schools or mixed ones [44].

Saying that, it is worth pointing that the argument behind concerns over the position of the Convention from single-sex schools has merits, taking into consideration the language of the Convention used to refute such argument. Article $10(\mathrm{C})$ explicitly states that encouraging coeducation and the revision of teaching methods and programs are methods adopted by the Convention to achieve the aimed objective of the elimination of any stereotyped concept of the roles of men and women [45].

As the case with the issues of abortion and family-related matters, the interpretation of the Convention's language would also determine the scope of the implementation process, which represents a vagueness that is not in favor of the Convention's lobbying efforts.

The legalization of prostitution is another concern for opponents of the ratification of CEDAW by the United States [46]. Such concern is a direct result to Article 6 of the Convention, which requires Member states to suppress all forms of women trafficking and exploitation of prostitution by all appropriate measures, including legalization [47]. Regarding Article 6, the wording of the article itself is supporting the protection of women in one of the areas that represent a considerable source of abuse and sexual exploitation. Such idea of providing protection for women from such abuse is not a dividing issue, where it is generally an agreed principle [48]. However, the controversy surrounds the interpretation of the Article on how this protection is to be provided [49]. Including legal measures, explicitly, in the article as one of the tools that enable Member states in providing such protection opens the door for an interpretation to the Article that presents the legalization and regulation of prostitution as one of the most effective ways to counter exploitation of prostitution of women, where prostitution would be regulated as a legitimate sector that is part of the overall economy, and laws will be introduced to provide legal protection of the rights of those who work in this sector [50]. 
The unwanted controversial interpretation, which is considered as one of the main factors that motivate lobby groups in the United States to pressure their government against a ratification of the Convention is evidenced in the Convention Committee's call for China to decriminalize and legalize prostitution [51]. Such call constitutes an evidence for many as to the unwanted line of interpretation adopted by the Convention's Committee.

Such concern is replied to by supporters of the Convention that neither the language nor the interpretation of Article 6 of the Convention require the legalization of prostitution, and that the intended regulation is only for the purpose of restricting trafficking and sex slavery practices, and allowing victimized women to participate in health care and education programs intended to deal with this issue without fear of repercussions [52]. Also, they argue that China's case was only an exception that resulted from the fact that prostitution and trafficking of women in China are rampant, which led the Committee to call for China to legalize prostitution as a tool to tighten the noose on sex traffickers and exploiters in the country [53].

However, such argument unintentionally supports the rational of the skeptics. It indirectly means that there is actually a possibility for China's case to be repeated and for the Article to be interpreted in favor of the legalization of prostitution if, according to its own reasoning, the Committee sees appropriate factors that warrant the need to do so. This view is supported by the fact that the interpretation of Article 6 in favor of the legalization of prostitution was indeed repeated, where the Committee has directed countries such as Sweden [54], Germany [55], and Liechtenstein [56] to consider a review on their laws with a view of introducing the legalization of prostitution, and responded positively to other countries' decriminalization of prostitution, such as the case with Greece [57].

\section{Analysis of the non-self-execution provision of CEDAW as a safeguard for the United States}

The debate above leads the discussion towards the issue of reservation as a procedure regulated by international law, and given to states to act as a safeguard for their interests against the obligations resulting from international treaties. In this regard, article 2 (d) of the Vienna Convention on the Law of Treaties defines reservation as a "unilateral statement, however phrased or named, made by a state, when signing, ratifying, accepting, approving, or acceding to a treaty, whereby it purports to exclude or modify the legal effect of certain provisions of the treaty in their application to that state [58]."

Conditions of reservation, which are generally regulated by the treaty subject of reservation itself, vary depending, with regards to their strictness or tolerance, on whether the priority of the treaty is the encouragement of wider participation by

DE GRUYTER OPEN 
states in the treaty, or the maximum protection of its integrity [59]. In relation to CEDAW, it seems that the Convention has set the wide participation by states around the world as a priority, when considering its position from the issue of reservation [60]. This is evident in the relatively large number of reservations by a considerable number of states that was accepted by the Convention despite the fact that some of these reservations touch, to an extent, the basics of the Convention [61].

As a result, one could ask as of why has not the United States ratified the Convention yet, considering that is has the right to make reservations on some aspects of the Convention's performance that take into account the sensitivities that could be imposed on its domestic laws and affairs.

If the United States decides to ratify the Convention, it is expected to do so with extensive reservations [62]. In fact, when the Convention was submitted to the Senate in 1980, the State Department included a memorandum identifying potential conflicts with United States law, and recommended appropriate reservations, understandings, and declarations to that effect [63]. The proposed reservations at the time were intended to express the intention of the United States of accepting no obligations under the Convention, in case of ratification, other than what is mandated by its constitution and laws in relation to issues of private conduct, women in military, comparable worth, and maternity leave [64].

The State Department, at the time, proposed three understandings along with the reservations. The first understanding relate to the protection of the freedom of speech under the First Amendment [65], and the other one relate to the discretion of the United States in determining the appropriate health care standards in relation to family planning, pregnancy, confinement and post-natal care [66]. The third understanding related to the intention of the United States, in case of acceptance, of not substituting federal legislation for state legislation on matters regulated by state and local governments [67].

The State Department also proposed, at the time, two declarations. The first states that the Convention is not self-executing with regards to the domestic law of the United States, which excludes the invocation of the Convention in its domestic court system [68]. The second declaration requires that the consent of the United States to the jurisdiction of the International Court of Justice will be based on a case-by-case status [69].

Prior to discussing the United States' potential position of declaring the Convention a non-self-executed treaty, it is relevant to examine the legal context of the term "self-execution" for international treaties.

Even though it becomes a commitment on a state party to an international treaty to carry out its obligations under the treaty, the approaches followed by states to incorporate the treaty into the domestic legal structure vary. Such incorporation can 
be automatic through a constitution provision or an executive decision, which mandates domestic enforcement for ratified international treaties without further legislative, judicial or executive measures beyond ratification under which the treaty will be considered as a self-executed treaty [70]. The incorporation may also require a special additional measure beyond ratification in order to give international treaties domestic effect.

In the United States, generally, the Federal government decides whether an international treaty is to be considered as self-executing treaty or non-selfexecuting one that needs to be implemented by legislation or appropriate executive measure [71].

In this regard, it could be argued that the potential position of the United States of stressing on the non-self-executing effect of the Convention, if it decides to go on with its ratification, downplays the argument of the Convention's detractors that the broadness of the Convention's scope would have far-reaching and undesirable impact in the United States [72]. According to this argument, the potential impact of ratification without a self-executing provision would be minimal, as the provisions of the Convention would not be held self-executing by the judicial system of the United States [73].

However, this argument ignores a view by constitutional scholars that human rights treaties, which grant specific rights or create an obligation to refrain from acting in a way, are generally considered self-executing, making any measure of the legislative bodies to declare an act of legislative non-recognition by considering a self-executing treaty as non-self-executing one; an act of violation of the separation of powers principle, as they consider the judicial authority, not legislative, as the one that has the power to apply treaty law, in cases of controversy, to cases before the court under Article III of the United States Constitution. Under this scholarly view, the judicial authority has the power to deem a treaty to be self-executing [74]. As an alternative, the domestic implementation of such treaty could be conducted through a Congress-passed legislation.

This view is clearly demonstrated in the case of the implementation of the International Covenant on Civil and Political Rights, which the United States ratified with five reservations, five understandings, and four declarations of which one of them declares that "the provisions of article 1 through 27 of the Covenant are not self-executing [75]". The United States courts, however, have expressed in cases such as Igartua-De Le Rosa v. US [76], and Fleming $v$ US [77], that "expressed declarations" do not affect treaty law and the rights of citizens, and established that the International Covenant on Civil and Political Rights treaty is a self-executing by the legal definition of a self-executing treaty. In fact, there is even a question of legitimacy with regards to the non-self-execution declaration under both the United States domestic law and international law. In the context of

DE GRUYTER OPEN 
Al Shraideh S. (2017)

CEDAW in the Eyes of the United States

United States law, the non-self-execution declaration is considered by many to be incompatible with the Supremacy Clause of the United States Constitution that consider ratified treaties under the authority of the United States as "Supreme Law of the Land", which is binding on federal, state and local governments [78]. Whereas in international law, the principle of pacta sunt servanda considers it illegitimate invoking the domestic legal system as a justification for failure to comply with a country's international law obligations [79]. Therefore, a treaty that has been ratified by the United States should be binding on its government as a matter of international law even if it was considered as non-self-executing and has not been implemented by a domestic legislation.

Other than the issue of direct incorporation of ratified international agreements into the United States' legal framework, the argument stressing on the significance of the non-self-execution clause as a safeguard against the broad and undesired impact of CEDAW on the domestic context, also ignores the precedent impact international law has been having on the validity of the Supreme Court decisions regardless to the issue of self-execution. In this context, the non-self-execution clause with a future United States ratification of the Convention, which would be supposed to prevent the invocation of the Convention in its courts, whether as a ground for defense or claim [80], does not actually mean, judging by the trend that has been followed by the Supreme Court, that, in practice, the Convention would not have an impact on the United States jurisprudence [81].

Recently, a trend has been followed by the United States Supreme Court of referring to international law as supporting evidence to strengthen its decisions' validity. In Lawrence v. Texas [82], the Court's decision that overruled a Texas Statute barring same-sex sodomy, referred to a decision by the European Court of Human Rights that allows for homosexual conduct to support its decision, showing that in relation to such conduct's legality, there is still a lack of consensus. In another case, Atkins v. Virginia the Court overlooked laws that allowed for the possibility of sentencing the mentally retarded to death, when it stated that there is a national consensus against the execution of the mentally retarded, referring in support of its conclusion to an amicus brief filed by the European Union, which states that "within the world community, the imposition of the death penalty for crimes committed by the mentally retarded offenders is overwhelmingly disapproved [83]"

In a more notable example, the Court stated in support of its decision in Roper $v$. Simmons against the imposition of the death penalty on juvenile offenders under eighteen years old that

The overwhelming weight of international opinion against the juvenile death penalty is not controlling here, but provides respected and significant confirmation for the Court's determination that the penalty is 
disproportionate punishment for offenders under 18...The United States is the only country in the world that continues to give official sanction to the juvenile penalty. It does not lesson fidelity to the Constitution or pride in its origins to acknowledge that the express affirmation of certain fundamental rights by other nations and peoples underscores the centrality of those same rights within our own heritage of freedom [84].

In a similar case, where the Court ruled against the imposition of the death penalty on persons under 16 years of age, it stated in Thompson v. Oklahoma that "[w]e have previously recognized the relevance of the views of the international community in determining whether or not a punishment is cruel and unusual [85]. These examples of the United States Supreme Court rulings clearly indicate that the Court views that there is no conflict between the United States legal system and the citation and utilization of international rules, principles, and practices as guidance in shaping its rulings. Therefore, whether there will be a non-selfexecution condition associated with the United States ratification of the Convention or not; it will have a great impact on its courts dealing with issues that would be interpreted to fall within the Convention's scope. In this regard, the broadness and, to some extent, the vagueness of how the Convention is dealing with the issue of gender equality, could affect the approach followed by the Court in the interpretation of the Convention, which would, in turn, impact the way it deals with some of the most sensitive issues in the American society.

Therefore, when taking all these domestic implementation issues into consideration, the potential non-self-execution declaration of the United States against the direct implementation of the CEDAW provisions, if ratified, might prove useless if challenged, which, in turn, consolidate the initial argument of the Convention's detractors of having a broad scope of its implementation with farreaching undesirable impact without the national legislation that acts as a safety valve against unwanted implications of such implementation.

\section{The continuing Stalling of CEDAW ratification between the implicit admission of opponents' rationale and the failure to realize its potential to the United States}

The opposing arguments presented by conservatives from the American society has managed so far to obstruct the United States ratification of CEDAW despite receiving bipartisan support that was reflected in the support of presidents Carter, Clinton, George W. Bush, and Obama, and the support over the years from both Democratic and Republican senators [86]. In addition, it has received the support of some civil society groups and associations, such as American Bar Association, and the League of Women Voters [87]. This support was also reflected in a

DE GRUYTER OPEN 
nationwide poll conducted in 2010 that found that 89 percent of respondents supported the ratification of the Convention by the United States [88].

In general, treaties enjoying bipartisan support, and considerable society support, are less likely to face hurdles during the ratification process in the United States [89]. However, the continuing position of the its government of not ratifying the Convention despite such support raises questions as to the validity of the arguments adopted by the opposition against the ratification. It, in indirect way, gives merits to such concerns, and indirectly acknowledges that they actually have a point in their rationale. By allowing the conservative wing to determine the fate of the Convention in the United States based on a specific rationale, the government sends a message that it cannot completely rule out what this rationale is based on, and that it is itself still not sure about the potential unwanted ramifications from such ratification on its domestic society.

On the other hand, it is worth mentioning that despite the fact that the above arguments are based on the view of the conservative Convention's opponents, who base their objection on the vagueness and broadness of the Convention's scope and its implications on the United States society; there is another direction of opposition to the Convention that is based on the exact opposite view [90]. Such opposition does not see an added value from the Convention into what they consider as an already "highly developed system of civil rights laws protecting women" in the United States. This direction of opposition views that the Convention is suffering from obvious flaws, with an emphasis on its lack of adequate enforcement mechanisms for compliance [91]. It argues that the fact that many countries that ratified the treaty are widely regarded to have poor women's rights records, and continue to follow discriminatory laws and practices against women despite being parties to CEDAW, makes the already implemented United States laws far more superior in providing protection for women then the toothless CEDAW [92]. On the contrary to the view of the conservative opposition, this line of opposition requires more compliance-related mandate and enforcement mechanism in the Convention in order to give its blessings for the United States ratification of CEDAW.

Despite the implementation-related problematic issues discussed above, it is still worth remembering the negative message that the failure of the American ratification of CEDAW is sending to the rest of the world. When excluding the threat or use of military force, the international perceived reputation of the United States greatly affects its international influence [93]. Regardless to how convincing the rationale used by the United States opponents of the convention in reasoning their opposition, its failure to ratify the Convention affects its ability to promote women's rights or criticize other countries' women-related policies and practices, when it is among the very few countries that have not ratified what is considered as 
a key women-rights treaty. This lack of legal recognition of CEDAW labels the international position of the United States with regard to women rights issues as weak and hypocrite, as it expects countries to adhere to international standards that it does not itself follow [94]. Therefore, the ratification of the Convention is viewed by many to increase the credibility of the United States actions in any quest to promote women rights internationally [95].

\section{Conclusion}

As discussed above, the outcome of the ratification process for CEDAW in the United States remains uncertain. Despite the fact that the Convention has received substantial domestic support, it has also been obstructed by a strong opposition that has managed to stall its ratification until now.

In this regard, it could be right to say that both supporters and opponents agree on CEDAW goals of protecting and promoting women's rights and eliminating gender discrimination, but disagree on the appropriateness of its mechanism to achieve such goals, considering the domestic structure of the United States. While some say that the Convention would blend in the already developed United States legal framework in the field of gender equality, adding value to such framework without conflicting with or overpowering the established domestic principles; others view it as an invasive sovereignty-threatening tool of unwanted international influence on a well-established legal system that already acknowledges and acts upon gender equality issues. The vagueness and broadness of the Convention, as viewed by its opponents, would contribute in creating the claimed undesired conflict with not only the legal system but also with some sensitive sociopolitical issues in the American texture. Such disagreement has been considerable enough to block any advancement in the domestic adoption of the Convention. However, putting aside the rationale and merits used to support or oppose the ratification of the United States of CEDAW, having the United States as one of the very few states in the world that are yet to join the Convention seems to many a little odd in a way that affects its international image and position in dealing with human rights issues in general, and women rights in particular.

\section{Bibliography}

1. Concerned for Women Legislative Action Committee, "CEDAW Harms Families", May 7, 2010, Beverly LaHaye Institute, https://concernedwomen.org/cedaw-harmsfamilies/, viewed on 2/10/2017.

2. Convention on the Elimination of All Forms of Discrimination Against Women (CEDAW), adopted and opened for signature, ratification and accession by the General Assembly Resolution 34/180 December 1979, entered into force on 3 September 1981, UN Treaty Series, Vol. 1249. 
3. Courtney Goldsworthy, "Why the United States Has Failed to Ratify the CEDAW: A Look at Purported Problems with Ratification", Michigan State University, 2005.

4. Christina Sommers, "Feminism by Treaty" Policy Review no. 167, (2011) 37-50.

5. David Auerswald, and Maltzman Forrest, "Policymaking Through Advice and Consent:

Treaty Consideration by the United States Senate." Journal of Politics, Vol. 65 (4), 2003.

6. Devaki Jain, Women, Development, and the UN: A Sixty-Year Quest for Equality and Justice, Bloomington: Indiana University Press, 2005.

7. "Discrimination Against Women (CEDAW): Issues in the U.S. Ratification Debate." Congressional Research Service, (2001), 7-5700.

8. Ed Pilkington, "US criticized by UN for human rights failings on NSA, guns and drones". The Guardian. April 2, 2014

9. F.Martin, International Human Rights and Humanitarian Law, Cambridge University Press, 2006.

10. Jamil Dakwar, "U.S. Human Rights Record Undergoes International Scrutiny". American Civil Liberties Union (ACLU), April 2, 2014.

11. Julia Schast, "Battle of the Sexes: Why the United States Has Not Yet Ratified the Convention on the Elimination of All Forms of Discrimination Against Women (CEDAW)", Elon University, http://www.elon.edu /eweb/academics/writing_excellence/contest/Contest\%20Entry\%20Schast\%20Research \%20Essay.xhtml, Viewed on 3/10/2017.

12. Julie Minor, "An analysis of structural Weaknesses in the Convention of the Elimination of All Forms of Discrimination against Women", 24 Georgia Journal of International \& Comparative Law, 137-153, (1997).

13. Kavita Ramdas and Kelly Janus Kathleen, "Ratifying Women's Rights." Policy Review no. 169, 2011.

14. Lynn Walter, Women's Rights: A Global View, Westport: Greenwood Press, 2001.

15. Malvina Halberstam, "The United States Ratification on the Convention on the Elimination of All Forms of Discrimination Against Women", 31(1) George Washington Journal of International Law \& Economy, 49-96, (1997).

16. Penny Wakefield, "CEDAW Ratification: Back Seated Once Again " Washington \& Lee Law School Human Rights 37(3), 2010.

17. Rebecca Cook, "State Accountability Under the Convention on the Elimination of All Forms of Discrimination Against Women, in Human Rights of Women: National and International Perspectives, University of Pennsylvania Press, 1994.

18. Report of the Committee on the Elimination of Discrimination against Women on its Eighteenth Session, General Assembly Official Records, Supplement No. 38 (A/ 53/ 38/ Rev.1), 1998.

19. Report of the Committee on the Elimination of Discrimination against Women on its Twentieth Session, General Assembly Official Records, Supplement No. 38 (A/ 54/ 38/ Rev.1), 1999. 
20. Report of the Committee on the Elimination of Discrimination against Women on its Twenty Second Session, General Assembly Official Records, Supplement No. 38 (A/ 55/ 38), 2000.

21. Report of the Committee on the Elimination of Discrimination against Women on its Twenty Fourth Session, General Assembly Official Records, Supplement No. 38 (A/ 56/ 38), 2001.

22. Susan Yoshihara, "Does CEDAW Promote Abortion?", Catholic Family \& Human Rights Institute, 2010

23. Thaler Kai, "50 years ago today, American diplomats endorsed mass killings in Indonesia. Here's what that means for today", The Washington Post, December 24, 2015.

24. Todd Landman, Protecting Human Rights: A Comparative Study, Georgetown University Press, 2005.

25. Trymaine Lee, "UN watchdog condemns US for human rights failures". MSNBC, April 2, 2014.

26. United Nations Department of Economic and Social Affairs, Division of Social Policy and Development, "International Norms and Standards Relating to Disability", (20032004), http://www.un.org/esa/socdev/enable/comp101.htm, Viewed on 3/10/2017.

27. UN General Assembly, Convention on the Elimination of All Forms of Discrimination Against Women (CEDAW), Resolution 34/180 December 18, 1979), General Recommendation 24.

28. UN Report of the World Conference of the International Women's Year, Mexico City, 19 June-2 July 1975.

29. U.S. Civil Rights Act of 1964 (Pub.L. 88-352, 78 Stat. 241, enacted July 2, 1964).

30. U.S. Senate Committee on Foreign Relations. 2002. "Treaty Doc. 96-53, " Hearing before the Committee on Foreign Relations. 107th Congress, 2nd Session. U.S. Government Printing Office: Washington. http://www.access.gpo.gov/congress/senate

31. Vienna Convention on the Law of Treaties, registered on 27 Jan 1969, entered into force on 27 Jan 1980, UN Treaty series, Vol. 1155.

32. William Gould, Agenda for Reform: The Future of Employment Relationships and the Law, MIT Press, 1996.

\section{Notes}

[1] Convention on the Elimination of All Forms of Discrimination Against Women (CEDAW), adopted and opened for signature, ratification and accession by the General Assembly Resolution 34/180 December 1979, entered into force on 3 September 1981, UN Treaty Series, Vol. 1249, P. 13.

[2] https://treaties.un.org/Pages/ViewDetails.aspx?src=TREATY\&mtdsg_no=IV-

$8 \&$ chapter $=4 \&$ lang $=$ en, viewed on $1 / 10 / 2017$.

[3] Ibid.

[4] UN Report of the World Conference of the International Women's Year, Mexico City, 19 June-2 July 1975.

[5] Walter, Lynn, Women's Rights: A Global View, Westport: Greenwood Press, 2001,at 17.

DE GRUYTER OPEN 
Al Shraideh S. (2017)

$C E D A W$ in the Eyes of the United States

[6] Jain, Devaki, Women, Development, and the UN: A Sixty-Year Quest for Equality and Justice, Bloomington: Indiana University Press, 2005, at 93.

[7] Convention on the Elimination of All Forms of Discrimination Against Women (CEDAW), above n. 1, Article 2.

[8] Ibid, Article 17. See also, Cook, Rebecca, "State Accountability Under the Convention on the Elimination of All Forms of Discrimination Against Women, in Human Rights of Women: National and International Perspectives, University of Pennsylvania Press, 1994, at 228-256, 247,

[9] Goldsworthy, Courtney, "Why the United States Has Failed to Ratify the CEDAW: A Look at Purported Problems with Ratification", Michigan State University, 2005, at 5.

[10] Pilkington, Ed, "US criticized by UN for human rights failings on NSA, guns and drones". The Guardian. April 2, 2014.

[11] Ibid.

[12] Ibid.

[13] Dakwar, Jamil, "U.S. Human Rights Record Undergoes International Scrutiny" American Civil Liberties Union (ACLU), April 2, 2014. See also, Trymaine Lee, "UN watchdog condemns US for human rights failures", MSNBC, April 2, 2014.

[14] Kai, Thaler, "50 years ago today, American diplomats endorsed mass killings in Indonesia. Here's what that means for today", The Washington Post, December 24, 2015. See also, Perry, Juliet, "Tribunal finds Indonesia guilty of 1965 genocide; US, UK complicit". CNN, June 5, 2017.

[15] Landman, Todd, Protecting Human Rights: A Comparative Study, Georgetown University Press, 2005, at 101-106.

[16] The United States Constitution, the Nineteenth Amendment extending the right of suffrage for women, 1919.

[17] The Civil Rights Act of 1964 (Pub.L. 88-352, 78 Stat. 241, enacted July 2, 1964). See Also, Gould, William, Agenda for Reform: The Future of Employment Relationships and the Law, MIT Press, 1996, at 27.

[18] The U.S. Equal Employment Opportunity Commission (EEOC) is a federal agency that administers and enforces civil rights laws against workplace discrimination. The EEOC investigates discrimination complaints based on an individual's race, children, national origin, religion, sex, age, disability, sexual orientation, gender identity, genetic information, and retaliation for reporting, participating in, and/or opposing a discriminatory practice.

[19] Auerswald, David, and Forrest, Maltzman "Policymaking Through Advice and Consent:

Treaty Consideration by the United States Senate.” Journal of Politics, Vol. 65 (4), 2003, at 1099.

[20] Ibid.

[21] Ibid.

[22] Ramdas, Kavita and Janus Kathleen, Kelly, "Ratifying Women's Rights." Policy Review no. 169, 2011, at 30-31.

[23] Goldsworthy, Courtney, above n. 9, at 8-9.

[24] Ibid, 9. 
[25] Concerned for Women Legislative Action Committee, "CEDAW Harms Families", May 7, 2010, Beverly LaHaye Institute, https://concernedwomen.org/cedaw-harmsfamilies/, Viewed on 2/10/2017.

[26] Goldsworthy, Courtney, above n. 10, at 9.

[27] Ibid

[28] Report of the Committee on the Elimination of Discrimination against Women on its Eighteenth Session, General Assembly Official Records, Supplement No. 38 (A/ 53/ 38/ Rev.1), 1998, Paragraph 97.

[29] Report of the Committee on the Elimination of Discrimination against Women on its Twenty Fourth Session, General Assembly Official Records, Supplement No. 38 (A/ 56/ 38), 2001, Paragraph 92.

[30] Report of the Committee on the Elimination of Discrimination against Women on its Twenty Second Session, General Assembly Official Records, Supplement No. 38 (A/ 55/ 38), 2000, Paragraph 408.

[31] Jackson, Thomas, "10 Reasons Why the United States Should not Ratify CEDAW: Harmful to Women, Children, Marriage, Families and American Constitutional Government", International Diplomacy \& Public Policy Center, http://www.idppcenter.com/cedaw-10_reasons_to_oppose.pdf, visited on 2/10/2017

[32] Goldsworthy, Courtney, above n. 9, at 9.

[33] Ibid.

[34] Ibid.

[35] Yoshihara, Susan, "Does CEDAW Promote Abortion?", Catholic Family \& Human Rights Institute, 2010, at 1.

[36] UN General Assembly, Convention on the Elimination of All Forms of Discrimination Against Women (CEDAW), Resolution 34/180) December 18, 1979), General Recommendation 24.

[37] Ibid.

[38] Dairian, Shanthai, CEDAW Committee Expert, statement at the Commission on the Status of Women, March 5, 2007.

[39] Ibid.

[40] Goldsworthy, Courtney, above n. 9, at 10.

[41] Ibid.

[42] Obergefell $v$. Hodges, Supreme Court of the United states, 576 U.S. 135 S. Ct. 2584; 192 L. Ed. 2d 609; 83 U.S.L.W. 4592; 25 Fla. L. Weekly Fed. S 472; 2015 WL 2473451; 2015 U.S. LEXIS 4250; 2015 BL 204553

[43] Goldsworthy, Courtney, above n. 9, at 11.

[44] Ibid.

[45] Convention on the Elimination of All Forms of Discrimination Against Women (CEDAW), above n. 1, Article 10 (C).

[46] Goldsworthy, Courtney, above n. 9, at 11.

[47] Convention on the Elimination of All Forms of Discrimination Against Women (CEDAW), above n. 1, Article 6.

[48] Jackson, Thomas, above n. 31, at 9.

[49] Ibid. 
Al Shraideh S. (2017)

CEDAW in the Eyes of the United States

[50] Ibid, at 9-10.

[51] Report of the Committee on the Elimination of Discrimination against Women on its Twentieth Session, General Assembly Official Records, Supplement No. 38 (A/ 54/ 38/ Rev.1), 1999, Paragraphs 288-289..

[52] Goldsworthy, Courtney, above n. 9, at 11.

[53] Ibid.

[54] Report of the Committee on the Elimination of Discrimination against Women on its Twenty Fourth Session, General Assembly Official Records, Supplement No. 38 (A/ 56/ 38), 2001, Paragraph 355.

[55] Report of the Committee on the Elimination of Discrimination against Women on its Twenty Second Session, General Assembly Official Records, Supplement No. 38 (A/ 55/ 38), 2000, Paragraph 25.

[56] Report of the Committee on the Elimination of Discrimination against Women on its Twentieth Session, General Assembly Official Records, Supplement No. 38 (A/ 54/ 38/ Rev.1), 1999, Paragraph 168.

[57] Ibid, Paragraph 197.

[58] Vienna Convention on the Law of Treaties, registered on 27 Jan 1969, entered into force on 27 Jan 1980, UN Treaty series, Vol. 1155, P.331.

[59] Minor, Julie, "An analysis of structural Weaknesses in the Convention of the Elimination of All Forms of Discrimination against Women", 24 Georgia Journal of International \& Comparative Law, 137-153, (1997) at 3

[60] Ibid.

[61] Ibid.

[62] Goldsworthy, Courtney, above n. 9, at 19.

[63] Minor, above n. 59, at 4.

[64] Halberstam, Malvina, "The United States Ratification on the Convention on the Elimination of All Forms of Discrimination Against Women, 31(1) George Washington Journal of International Law \& Economy, 49-96, (1997), at 56.

[65] Ibid, at 58.

[66] Ibid.

[67] Ibid.

[68] Minor, above n. 59, at 60

[69] Ibid.

[70] United Nations Department of Economic and Social Affairs, Division of Social Policy and Development, "International Norms and Standards Relating to Disability", (20032004), http://www.un.org/esa/socdev/enable/comp101.htm , Viewed on 3/10/2017.

[71] Ibid.

[72] Goldsworthy, Courtney, above n. 9, at 22.

[73] Ibid, at 23.

[74] Martin, F., International Human Rights and Humanitarian Law, Cambridge University Press, 2006, at 221.

[75] U.S. reservations, declarations, and understandings, International Covenant on Civil and Political Rights, 138 Cong. Rec. S4781-01 (daily ed., April 2, 1992)

[76] Igartua-De Le Rosa v. US, 417 F.3d 145, 190-191 (1st Cir. 2005) 
[77] Fleming v US (15-8425)

[78] United Nations Department of Economic and Social Affairs, Division of Social Policy and Development, "International Norms and Standards Relating to Disability", (20032004), http://www.un.org/esa/socdev/enable/comp101.htm, Viewed on 3/10/2017.

[79] The Vienna Convention on the Law of Treaties, signed at Vienna on May 23, 1969, entered into force on January 27, 1980, art. 26

[80] Minor, above n. 59, at 60

[81] Goldsworthy, Courtney, above n. 9, at 25.

[82] Lawrence v. Texas , 539 US 558 (2003).

[83] Atkins v. Virginia, 536 US 316-317 (2002).

[84] Roper v. Simmons, 125 S. Ct. 1183 (2005)

[85] Thompson v. Oklahoma, 487 U.S. 831 (1988).

[86] Sommers, Christina, "Feminism by Treaty." Policy Review no. 167, (2011) 37-50, at 38.

[87] Ibid.

[88] Wakefield, Penny, "CEDAW Ratification: Back Seated Once Again " Washington \& Lee Law School Human Rights 37(3), 2010, at 22.

[89] Schast, Julia, "Battle of the Sexes: Why the United States Has Not Yet Ratified the Convention on the Elimination of All Forms of Discrimination Against Women (CEDAW)", Elon University, at 40, http://www.elon.edu/e-web/academics/writing

excellence/contest/Contest\%20Entry\%20Schast\%20Research\%20Essay.xhtml, Viewed on 3/10/2017.

[90] Ibid.

[91] Senate Committee on Foreign Relations. 2002. "Treaty Doc. 96-53," Hearing before the Committee on Foreign Relations. 107th Congress, 2nd Session. U.S. Government Printing Office: Washington. http://www.access.gpo.gov/congress/senate

[92] Blanchfield, Luisa, "The U.N. Convention on the Elimination of All Forms of Discrimination Against Women (CEDAW): Issues in the U.S. Ratification Debate." Congressional Research Service, (2001), 7-5700, at 9.

[93] Senate Committee on Foreign Relations. 2002, above n. 92, at $26 \& 48$.

[94] Blanchfield, Luisa, above n. 92, at 12.

[95] Ibid, at 11-12. 